\title{
Risk Factors for the Occurrence of Methicillin-Resistant Staphylococcus aureus in Dairy Herds: An Update
}

\author{
Arne Schnitt and Bernd-Alois Tenhagen
}

\begin{abstract}
In dairy cows, Staphylococcus aureus is a major mastitis pathogen and methicillin-resistant S. aureus (MRSA) has been reported from dairy farms around the world. The risk of foodborne zoonotic infections with bovine MRSA strains seems to be low since MRSA prevalence is low in dairy herds and milk is commonly heat treated before consumption. However, bovine mastitis caused by MRSA is an important issue in veterinary medicine since treatment options with non- $\beta$-lactam antibiotics are limited. For the development of effective MRSA prevention strategies, it is necessary to know which factors increase the risk for MRSA transmission into and within dairy herds. Therefore, the aim of this review is to summarize the risk factors for the occurrence of MRSA in dairy herds and to identify the respective knowledge gaps. MRSA was more frequently detected in conventional dairy farms than in organic farms and in larger farms than in smaller farms. Dairy farms housing pigs along with cattle are more frequently affected by MRSA. Moreover, humans carrying MRSA can probably infect dairy cows. Consequently, pigs and humans may introduce new MRSA strains into dairy herds. MRSA transmission within dairy herds was associated with improper milking hygiene procedures. Furthermore, methicillin-resistant coagulase-negative staphylococci (MR-CoNS) were repeatedly isolated from dairy farms. This is an important issue since MR-CoNS may transfer resistance genes to $S$. aureus. The role of antimicrobial exposure as a risk factor for the occurrence of MRSA within dairy herds needs to be further investigated.
\end{abstract}

Keywords: methicillin, staphylococcus, MRSA, dairy, milk

\section{Introduction}

$S$ TAPHYLOCOCCUS AUREUS IS considered a contagious mastitis pathogen that enters the mammary gland through the teat canal. In most cases there is one predominant $S$. aureus strain that affects multiple cows and spreads from cow to cow within dairy herds (Zadoks et al., 2000; Barkema et al., 2006; Keefe, 2012). Thus, the primary risk period for $S$. aureus transmission is during the milking process. The usual routes of transmission are milkers' hands, udder cloths, and milking equipment such as teat liners.

The overall prevalence of mastitis pathogens is highly variable and differs between herds and regions. To date, the most common pathogens causing clinical mastitis seem to be environmental streptococci and coliform bacteria followed by $S$. aureus (Ruegg, 2018). In some studies, S. aureus is still the most prevalent pathogen isolated from mastitis milk samples (Østerås, 2018).
In $S$. aureus, methicillin resistance is mediated by a mecAor $m e c C$ - gene. This gene is located on a mobile genetic element called "staphylococcal cassette chromosome mec" (SCCmec). The gene is responsible for the production of an altered penicillin-binding protein $2 \mathrm{a}(\mathrm{PBP} 2 \mathrm{a})$. The PBP2a has a lower affinity for $\beta$-lactam antimicrobials than the normal PBP. Thus, mecA-/mec $C$-positive staphylococci are resistant to most $\beta$-lactam antibiotics (Holmes and Zadoks, 2011; Miragaia, 2018).

While cure rates for lactational $S$. aureus treatments are low, dry cow therapy (DCT) is typically more effective (Keefe, 2012). Most frequently recommended dry cow antibiotics for the treatment of methicillin-sensitive $S$. aureus (MSSA) infections contain $\beta$-lactams (Tenhagen et al., 2006; Saini et al., 2012a). Especially cloxacillin is extensively used on dairy farms and cure rates for dry cow treatment of $S$. aureus infections with cloxacillin were reported to range up to $98 \%$ (Makovec and Ruegg, 2003a; Tenhagen et al., 2006;

\footnotetext{
Department Biological Safety, German Federal Institute for Risk Assessment, Berlin, Germany.

(C) Arne Schnitt and Bernd-Alois Tenhagen 2020; Published by Mary Ann Liebert, Inc. This Open Access article is distributed under the terms of the Creative Commons Attribution Noncommercial License (http://creativecommons.org/licenses/by-nc/4.0/) which permits any noncommercial use, distribution, and reproduction in any medium, provided the original author(s) and the source are cited.
} 
Saini et al., 2012c). Although, there are no studies on antibiotic treatment outcomes for mastitis caused by methicillinresistant $S$. aureus (MRSA), cloxacillin, and other $\beta$-lactams are probably ineffective. Consequently, culling might be the only chance to remove MRSA from dairy herds. In addition, MRSA in dairy cows is of human health concern since people working on dairy farms were shown to carry similar MRSA strains as their cows ( Juhasz-Kaszanyitzky et al., 2007; Hata et al., 2010; Spohr et al., 2011; Lim et al., 2013; Locatelli et al., 2017). In these studies, the direction of transmission remained unclear. MRSA transmission from cows to consumers of milk seems unlikely due to commonly practiced heat treatment. However, the consumption of raw milk is a possible source of infection (Al-Ashmawy et al., 2016; Parisi et al., 2016). This might be an issue since many dairy farmers and their families consume raw milk and the number of raw milk vending machines is increasing in Europe (www .milkmaps.com). Thus, MRSA in dairy herds represents a possible health hazard for both humans and cattle. The objective of this review is to summarize the risk factors for the occurrence and spread of MRSA in dairy herds and to identify the respective knowledge gaps.

\section{Prevalence and Epidemiology of MRSA in Dairy Herds}

The detection of S. aureus in dairy cows is demanding due to its intermittent shedding patterns in milk (Barkema et al., 2006; Keefe, 2012). Comparison of MRSA prevalence studies is additionally challenging because of differences in types of samples, inoculum volumes, (pre-) enrichment, and detection methods.

MRSA prevalence (mecA/mecC) in bulk tank milk (BTM) has been previously reported to range from $0 \%$ to $20 \%$ (Table 1). A study from Sicily found a significantly higher MRSA prevalence of $43.8 \%$ in BTM from dairy farms (Antoci et al., 2013). This high prevalence was presumably caused by the preselection of dairy farms that had been tested positive for MRSA in previous years. The average MRSA prevalence from all other BTM samples in Table 1 is $\sim 2.9 \%$. The majority of studies (76\%) are from Europe. MRSA prevalence was significantly lower in BTM samples from the United States with 0.3\% (3/980) (Virgin et al., 2009; Haran et al., 2012; Cicconi-Hogan et al., 2014). Compared with Europe, MRSA prevalence was also lower in pig herds from the United States (Sun et al., 2015; Abreu et al., 2019). As shown in Table 2, the MRSA prevalence of S. aureus mastitis isolates was reported to be between $0 \%$ and $49 \%$. The average MRSA prevalence of all individual milk samples in Table 2 is $\sim 4.5 \%$. The MRSA prevalence within individual dairy herds is shown in Table 3 . The highest within-herd prevalence of MRSA was 39.7\% (31/78) in Japan, 44\% (11/ $25)$ in Sweden, and $60 \%(n=33 / 55)$ in a herd from Italy (Hata, 2016; Locatelli et al., 2017; Unnerstad et al., 2018).

The overall MRSA prevalence in dairy herds is low, compared with other animal species, especially pigs. However, reports from Korea and Germany indicate that MRSA prevalence rates might be increasing over time. In Germany, the prevalence of MRSA-positive BTM samples increased from $4.1 \%$ in 2009 over $4.7 \%$ in 2010 to $9.7 \%$ in 2014 (Tenhagen et al., 2014, 2018). The German studies included BTM samples from all over Germany. The studies were performed under similar conditions within the framework of a national monitoring program. In Korea, MRSA prevalence was up to $6 \%$ until 2003 and 13.9\% in 2011-2012 (Kwon et al., 2005; Moon et al., 2007; Song et al., 2016). The Korean studies tested mastitis milk samples from different regions in Korea and their comparability is therefore difficult to evaluate. The authors of the last study concluded that the prevalence of MRSA in mastitis milk has continuously increased in Korea (Song et al., 2016). In conclusion, there is some evidence that MRSA prevalence might be increasing in some countries.

In Europe, livestock-associated MRSA (LA-MRSA) belonging to clonal complex 398 (CC398) are the predominant MRSA strains in dairy herds. They were repeatedly isolated from milk samples (Fessler et al., 2010; Vanderhaeghen et al., 2010; Kreausukon et al., 2012; Paterson et al., 2012; Tavakol et al., 2012; Tenhagen et al., 2014, 2018; Luini et al.,

Table 1. Methicillin-Resistant Staphylococcus aureus Prevalence in Bulk Tank Milk from Dairy Cows

\begin{tabular}{lccl}
\hline References & MRSA in BTM $\%(\mathrm{n}=$ MRSA $/ \mathrm{n}=$ samples $)$ & Year $(s)$ of collection & \multicolumn{1}{c}{ Country } \\
\hline Antoci et al. $(2013)$ & $43.8(21 / 48)$ & 2010 & Italy \\
Cicconi-Hogan et al. (2014) & $0.03(1 / 288)$ & $2009-2011$ & United States \\
Cortimiglia et al. $(2016)$ & $3.8(32 / 844)$ & $2012-2013$ & Italy \\
Haran et al. $(2012)$ & $1.3(2 / 150)$ & 2009 & United States \\
Kreausukon et al. $(2012)$ & $4.4(28 / 635)$ & $2009-2010$ & Germany \\
Locatelli et al. (2016) & $4.0(9 / 224)$ & 2011 & Italy \\
Obaidat et al. $(2018)$ & $20.0(16 / 80)$ & $2015-2016$ & Jordan \\
Papadopoulos et al. (2018) & $10.0(1 / 10)$ & 2016 & Greece \\
Parisi et al. $(2016)$ & $2.5(12 / 486)$ & $2012-2013$ & Italy \\
Paterson et al. $(2012)$ & $0.5(7 / 1500)$ & 2012 & United Kingdom \\
Paterson et al. $(2014)$ & $2.4(11 / 465)$ & $2011-2012$ & United Kingdom \\
Ronco et al. $(2018)$ & $0.0(0 / 94)$ & 2016 & Denmark \\
Tenhagen et al. $(2014)$ & $4.4(28 / 635)$ & $2009-2010$ & Germany \\
Tenhagen et al. $(2018)$ & $9.7(36 / 372)$ & 2007 & Germany \\
Virgin et al. (2009) & $0.0(0 / 542)$ & - & United States \\
Visciano et al. (2014) & $0.0(0 / 30)$ & - & Czech Republic, Slovakia \\
Vyletělova et al. $(2011)$ & $2.8(20 / 703)$ & &
\end{tabular}

MRSA was defined as $m e c A / m e c C$-positive $S$. aureus strains.

BTM, bulk tank milk; MRSA, methicillin-resistant $S$. aureus. 
Table 2. Methicillin-Resistant STaphylococcus aureus Prevalence of Staphylococcus Aureus Isolates Detected in Individual Milk Samples from More Than One Farm

\begin{tabular}{|c|c|c|c|c|}
\hline References & $\begin{array}{l}\text { Total } \\
\text { No. of } \\
\text { milk } \\
\text { samples } \\
\text { (n) }\end{array}$ & $\begin{array}{c}\% \\
\text { MRSA of } \\
\text { S. aureus } \\
\text { isolates } \\
\left(\mathrm{n}=\begin{array}{c}\text { MRSA } / \mathrm{n} \\
\text { aureus })\end{array}=\mathrm{S} .\right.\end{array}$ & $\begin{array}{l}\text { Year }(s) \text { of } \\
\text { collection }\end{array}$ & Country \\
\hline Ahangari et al. (2017) & - & $1.3(1 / 75)$ & 2014-2015 & Iran \\
\hline Aslantas and Demir (2016) & 330 & $4.5(5 / 112)$ & $2008-2010$ & Turkey \\
\hline Bao et al. (2016) & 121 & $9.6(5 / 52)$ & - & China \\
\hline Bardiau et al. (2013) & - & $4.4(19 / 430)$ & $2005-2008$ & Belgium \\
\hline Bengtsson et al. (2009) & 987 & $0(0 / 211)$ & $2002-2003$ & Sweden \\
\hline Bervoets (2009) & - & $0(0 / 550)$ & - & Canada \\
\hline Dan et al. (2018) & 186 & $16.3(16 / 98)$ & - & China \\
\hline da Costa Krewer et al. (2015) & 2064 & $0(0 / 126)$ & - & Brazil \\
\hline de Jong et al. (2018) & - & $1.6(3 / 192)$ & 2009-2012 & Europe \\
\hline Gindonis et al. (2013) & - & $1.5(2 / 135)$ & $2005-2006$ & Finland \\
\hline Haenni et al. (2011) & - & $0.7(1 / 139)$ & $2007-2008$ & France \\
\hline Huber et al. (2010) & - & $1.4(2 / 142)$ & 2009 & Switzerland \\
\hline Jamali et al. (2014) & 207 & $11.6(5 / 43)$ & $2008-2010$ & Iran \\
\hline Jamali et al. (2015) & 1035 & $13(21 / 162)$ & $2006-2013$ & Iran \\
\hline Kamal et al. (2013) & 35 & $9.1(3 / 33)$ & 2011-2012 & Egypt \\
\hline Kumar et al. (2010) & 185 & $7.8(10 / 128)$ & 2007-2008 & India \\
\hline Kwon et al. (2005) & 9055 & $6.0(15 / 248)$ & $\begin{array}{c}1999,2000, \\
2003\end{array}$ & Korea \\
\hline Lee $(2003)$ & 894 & $1.3(12 / 265)$ & $2001-2003$ & Korea \\
\hline Li et al. (2015) & 214 & $0.8(1 / 121)$ & - & China \\
\hline Luini et al. (2015) & - & $9.2(15 / 163)$ & 2006-2013 & Italy \\
\hline Mekonnen et al. (2018) & - & $0(0 / 79)$ & 2014-2016 & Ethiopia \\
\hline Moon et al. (2007) & 3047 & $1.6(13 / 835)$ & 1997-2004 & Korea \\
\hline Oliveira et al. (2016) & 552 & $32.3(21 / 65)$ & - & Brazil \\
\hline Pu et al. (2014) & 450 & $49.6(49 / 103)$ & 2008 & China \\
\hline Qu et al. (2018) & - & $4(15 / 96)$ & 2014-2017 & China \\
\hline Riva et al. (2015) & 383 & $20.0(7 / 35)$ & 2012 & Italy \\
\hline Rola et al. (2015) & 115 & $0(0 / 71)$ & 2009-2013 & Poland \\
\hline Ronco et al. (2018) & - & $1.6(1 / 63)$ & 2016 & Denmark \\
\hline Ruegg et al. (2015) & - & $0(0 / 35)$ & 2010 & United States \\
\hline Saini et al. (2012b) & - & $0.1(1 / 1810)$ & - & Canada \\
\hline Shrivastava et al. (2018) & 400 & $23.0(57 / 248)$ & - & India \\
\hline Song et al. (2016) & 649 & $13.9(23 / 165)$ & 2011-2012 & Korea \\
\hline Turkyilmaz et al. (2010) & - & $17.2(16 / 93)$ & $2002-2006$ & Turkey \\
\hline Unnerstad et al. (2013) & 8757 & $0.8(4 / 534)$ & $2010-2011$ & Sweden \\
\hline Vanderhaeghen et al. (2010) & - & $9.3(11 / 118)$ & $2006-2007$ & Belgium \\
\hline Vyletělova et al. (2011) & 724 & $1.7(3 / 180)$ & - & $\begin{array}{l}\text { Czech Republic, } \\
\text { Slovakia }\end{array}$ \\
\hline
\end{tabular}

MRSA was defined as mecA/mecC-positive $S$. aureus strains.

MRSA, methicillin-resistant $S$. aureus.

Table 3. Methicillin-Resistant Staphylococcus aureus Prevalence in Single Dairy Herds

\begin{tabular}{|c|c|c|c|}
\hline References & $\%$ MRSA prevalence $(\mathrm{n}=M R S A / \mathrm{n}=$ number of cows $)$ & Year(s) of collection & Country \\
\hline Hata (2016) & $39.7(31 / 78)$ & 2005 & Japan \\
\hline Locatelli et al. (2017) & Farm A $4.8(3 / 63)$, Farm B $60.0(33 / 55)$ & 2010 & Italy \\
\hline Magro et al. (2018) & $12.5(3 / 24)$ & — & Italy \\
\hline Matyi et al. (2013) & $5.3(7 / 133)$ & - & United States \\
\hline Falk (2018) & $13.2(139 / 1050)$ & 2018 & Israel \\
\hline Schlotter et al. (2014) & $28.6(16 / 56)$ & 2013 & Germany \\
\hline Silva et al. (2014) & $11.0(4 / 36)$ & - & Brazil \\
\hline Spohr et al. (2011) & Farm A 7.5 (12/160), Farm B 16.7 (7/42), Farm C 5.1 (4/78) & 2008 & Germany \\
\hline Unnerstad et al. (2018) & $44(11 / 25)$ & 2012 & Sweden \\
\hline
\end{tabular}

MRSA was defined as $m e c A / m e c C$-positive $S$. aureus strains.

MRSA, methicillin-resistant $S$. aureus. 
2015; Cortimiglia et al., 2016; Parisi et al., 2016; Locatelli et al., 2017; Ronco et al., 2018). Studies from Brazil, China, and Israel also found LA-MRSA CC398 in mastitis milk samples (Silva et al., 2014; Falk, 2018; Yi et al., 2018). Furthermore, LA-MRSA CC398 was found in nasal swabs and in udder cleft swabs from dairy cows (Antoci et al., 2013; Nemeghaire et al., 2014; van Duijkeren et al., 2014). The predominant LA-MRSA in Southeast Asia is multilocus sequence type 9 (ST9). It was also detected in milk samples (Wang et al., 2012; Tenhagen et al., 2018). In most studies, predominant MRSA strains were found within herds, suggesting a contagious transmission from cow to cow (Moon et al., 2007; Holmes and Zadoks, 2011; Schlotter et al., 2014; Luini et al., 2015; Song et al., 2016). However, a study from Italy reported a high heterogeneity of MRSA CC, spa-types, and genotypes within two dairy herds (Locatelli et al., 2017). The authors concluded that the environment could act as a reservoir of these MRSA strains.

In 2011, a new mec $A$ homolog $\left(m e c A_{L G A 251}\right)$ was identified in isolates from milk samples that were phenotypically resistant to methicillin but tested negative for the mecA gene (GarciaAlvarez et al., 2011). This new mecA homolog is also known as mecC and is often carried by strains belonging to clonal complex 130 (CC130). Zoonotic transmission has been reported for mecC-CC130 MRSA (Harrison et al., 2013). As of this writing, mec $C$-positive milk samples have been reported from Finland, the United Kingdom, Germany, and Sweden (Garcia-Alvarez et al., 2011; Gindonis et al., 2013; Unnerstad et al., 2013; Paterson et al., 2014; Schlotter et al., 2014). In a review about MRSA in human and bovine mastitis, the authors additionally reported mecC-positive bovine $S$. aureus isolates from Portugal, Denmark, and France (Holmes and Zadoks, 2011). However, according to the authors, these findings had not been published and were based on personal communications.

\section{Risk Factors for the Occurrence of MRSA in Dairy Herds}

\section{Improper milking hygiene}

Proper milking hygiene and especially the use of postmilking teat disinfectants are important control strategies for S. aureus mastitis (Barkema et al., 2006). In the past several decades, progressive use of milking hygiene procedures and other recommendations from the National Mastitis Council 5- and 10-point plan have led to a reduction in the prevalence of contagious mastitis pathogens in many countries (Makovec and Ruegg, 2003b; Barkema et al., 2006; Ruegg, 2018).

A recent case study from Brazil reported a high MRSA prevalence $(12.2 \%)$ in mastitis milk samples from one herd (Guimaraes et al., 2017). The authors observed a lack of preand postdipping procedures, udder towels were used on more than one cow, and the use of gloves was inappropriate. On the farm with the highest overall MRSA prevalence (60\%) in Italy, milkers were not using gloves (Locatelli et al., 2017). In a study from Sicily, the milking hygiene score was negatively correlated with MRSA prevalence (Antoci et al., 2013). The authors concluded that improper milking hygiene procedures may be a risk factor for MRSA transmission within dairy herds.

\section{Contact with pigs}

The most frequently detected bovine MRSA strain in Europe (CC398) was initially associated with pigs (Armand-
Lefevre et al., 2005; Voss et al., 2005; Huijsdens et al., 2006). In all studies on LA-MRSA CC398 in farm animals, pigs were most frequently affected and prevalence rates were up to $89 \%$ (Porrero et al., 2012; Abreu et al., 2019). Thus, it was assumed that pigs may transfer MRSA to bovines. A recent study on 844 dairy herds from Italy has not found any association between the MRSA status and the presence of any other animal species on the same farm (Cortimiglia et al., 2016). In contrast, two studies from the Netherlands have found that $64 \%(9 / 14)$ and $47 \%(28 / 60)$ of MRSA-positive farms harbored cows and pigs (Olde Riekerink et al., 2009; Tavakol et al., 2012). Another Italian study has reported that both the number of pigs and the number of pig herds close to the dairy farms were associated with the MRSA status (Locatelli et al., 2016). The authors have not only reported CC398 but also CC97 MRSA strains. An Italian study which analyzed CC97 MRSA isolates from pigs and cattle reported that all strains were very similar and that the detected clone spreads among pig and dairy cattle holdings in Italy (Feltrin et al., 2016). One MRSA-affected dairy farm from Germany also housed dairy cows and pigs. The same spa-type (t011) was found in the dairy cows and in the pig stall environment. The authors concluded that transmission might occur between the two livestock holdings (Spohr et al., 2011). Therefore, certain MRSA strains, especially those of CC398, can probably spread between pigs and cows. Possible routes of transmission between the stables are dust (wind), rodents, people working with both species, and equipment used in both parts of the farm (van de Giessen et al., 2009; Graveland et al., 2010; Visciano et al., 2014).

\section{Humans carrying MRSA}

Epidemiological investigations have suggested that sequence types of bovine and human $S$. aureus strains are usually different, and the risk of zoonotic and reverse zoonotic transmission is low (Holmes and Zadoks, 2011; Fitzgerald, 2012; Fluit, 2012). This seems to be different for MRSA, where the majority of isolates are considered LAMRSA strains that infect or colonize both, humans and cattle.

Additionally, several reports of community and health care-associated MRSA (CA-/HA-MRSA) strains in dairy cows were published (Table 4). A case report from Australia has found a CA-MRSA strain (ST1, t127-IV), also known as WA-MRSA-1, in a milk sample of a subclinical mastitis case (Abraham et al., 2017). According to the authors, WAMRSA-1 is one of the most prevalent CA-MRSA strains circulating in Australia. Whole-genome sequencing has proved that both MRSA strains carried similar resistance and virulence genes. The authors concluded that transmission might have occurred from humans to the dairy cow. Unfortunately, the authors could not obtain samples from the farm personnel to confirm this hypothesis. Molecular analysis of human and bovine ST1-MRSA stains in Italy showed several human-associated genetic features in bovine isolates (Alba et al., 2015). Other cases of CA-MRSA ST1, t127 in cattle, were reported from Germany, Italy, Switzerland, and Hungary (Juhasz-Kaszanyitzky et al., 2007; Huber et al., 2010; Pilla et al., 2012; Tenhagen et al., 2018). The authors from Italy assumed that humans were probably the source of infection, since the infected cow was kept on a closed farm (Pilla et al., 2012). HA-MRSA was found in dairy cows in 
Table 4. Reports of Community and Health Care-Associated Methicillin-Resistant STAPHylococcus aUReus IsOlates IN SAMPles FROM DAIRY COWS

\begin{tabular}{llcl}
\hline References & MLST//spa-type/SCCmec type of MRSA & Year(s) of collection & Country \\
\hline Abraham et al. $(2017)$ & ST1/t127/IV & 2015 & Australia \\
Bardiau et al. $(2013)$ & ST8/t008/IV & $2005-2008$ & Belgium \\
Haenni et al. $(2011)$ & ST5/t002/I & $2007-2008$ & France \\
Haran et al. $(2012)$ & ST8/t121/IVa, ST5/-/II & 2009 & United States \\
Hata et al. $(2010)$ & ST5/t002/II, ST89/t5266/IIIa & $1998-2005$ & Japan \\
Huber et al. $(2010)$ & ST1/t127/IV & 2009 & Switzerland \\
Juhasz-Kaszanyitzky et al. (2007) & ST1/t127/IV & $2002-2004$ & Hungary \\
Luini et al. (2015) & ST1/t127/IV, ST8/t3092/V & - & Italy \\
Magro et al. $(2018)$ & ST22/-/- & - & Italy \\
Monecke et al. $(2007)$ & ST8/t068/- & $2003-2009$ & Korea \\
Nam et al. $(2011)$ & ST72/t324/IVa & $2012-2013$ & Italy \\
Parisi et al. (2016) & ST1/t127/IVa, ST5/t688/V, ST8/-/IVa, V & - & Italy \\
Pilla et al. $(2012)$ & ST1/t127/IV & $2011-2012$ & Korea \\
Song et al. (2016) & -/t148/IVa & 2014 & Germany \\
Tenhagen et al. $(2018)$ & ST1/t127/-, ST22/t790/- & $2002-2006$ & Turkey \\
Turkyilmaz et al. (2010) & ST239/t030/III, ST8/t190/IV & & \\
\hline
\end{tabular}

MRSA was defined as $m e c A / m e c C$-positive $S$. aureus strains.

MLST, multilocus sequence typing; MRSA, methicillin-resistant $S$. aureus; SCCmec, staphylococcal cassette chromosome mec.

Germany (ST22), Japan (ST5), the United States (ST5), and Turkey (ST239) (Hata et al., 2010; Turkyilmaz et al., 2010; Haran et al., 2012; Tenhagen et al., 2018). In Korea CAMRSA (ST72, t324-IVa) and HA-MRSA (t148-IVa) were detected in milk samples (Nam et al., 2011; Song et al., 2016). A study from France reported the human-associated epidemic Geraldine-MRSA clone (ST5, t002-I) in a bovine milk sample (Haenni et al., 2011). In conclusion, CA- and HA-MRSA may be transferred to dairy cows. In light of the increasing numbers of CA- and HA-MRSA isolates in samples from cattle, the relevance of reverse zoonotic MRSA transmission might be underestimated.

\section{Production system}

A study from the United States has reported that S. aureus isolates from organic farms were phenotypically more susceptible to antimicrobials than isolates from conventional farms (Tikofsky et al., 2003). In contrast, a study from Denmark has not found a significant difference in susceptibility to penicillin between $S$. aureus isolates from organic and conventional farms (Bennedsgaard et al., 2006).

Currently, only two MRSA (mecA/mecC) prevalence studies have differentiated between organic and conventional production systems. One study from the United States tested BTM from 192 organic and 100 conventional farms for the $m e c A / m e C$ gene (Cicconi-Hogan et al., 2014). The authors only found one MRSA isolate in all farms and concluded that MRSA prevalence is low independent of the production system. The other study included 372 conventional and 303 organic BTM samples from Germany (Tenhagen et al., 2018). The MRSA prevalence was lower in organic herds $(1.7 \%)$ than in conventional herds $(9.7 \%)$. Consequently, there is some evidence that cows from conventional farms are more likely to carry MRSA than cows from organic farms.

\section{Herd size}

Two studies reported positive correlations between herd size and MRSA prevalence. In Germany, the prevalence of
MRSA in BTM was higher on conventional farms with a larger herd size than on small farms (Tenhagen et al., 2018). An Italian study found the highest $S$. aureus prevalence $(68.5 \%)$ in BTM samples from Sondrio province, where farms are small (median value 20 animals) (Cortimiglia et al., 2016). In contrast, the highest MRSA prevalences of $10.8 \%$ and $6.4 \%$ were reported from the provinces of Cremona and Lodi, where the median herd size was the highest in this study (325 and 278 cows/herd, respectively). In another Italian study, the average size of dairy herds tended to be positively correlated with MRSA status $(p=0.08)$ (Locatelli et al., 2016). On larger farms, more cows contribute to the BTM, increasing the likelihood of a positive BTM with a given cow level prevalence. Higher numbers of trading contacts and a higher use of third-generation cephalosporins may also contribute to a higher MRSA prevalence in BTM from large dairy herds (Saini et al., 2012a). However, smaller farms are probably more likely to keep multiple animal species, including pigs. This is also considered a risk factor for the presence of MRSA in a dairy herd.

\section{Methicillin-Resistant Coagulase-Negative- Staphylococci}

Coagulase-negative staphylococci (CoNS) are a diverse group of predominantly opportunistic pathogens. In several studies, CoNS were the most frequently detected organisms from milk samples (Pitkälä et al., 2004; Sampimon et al., 2009; Tenhagen et al., 2009; Oliveira et al., 2016). Molecular studies suggest that CoNS carry fewer virulence genes than $S$. aureus and are therefore considered less pathogenic (ÅvallJääskeläinen et al., 2018). In China, 73\% (82/112) of nonaureus staphylococci carried the mecA gene and MRSA prevalence was 4\% (15/96) (Qu et al., 2018). A study from the United States has reported 11 methicillin-resistant coagulase-negative staphylococci (MR-CoNS) in BTM from 288 farms and just 1 single MRSA isolate (Cicconi-Hogan et al., 2014). In contrast, in 3047 mastitis milk samples from Korea, the authors reported 12 MR-CoNS and 13 MRSA 
isolates (Moon et al., 2007). This would be in line with the lower virulence of the MR-CoNS. The last VetPath study from Europe reported that 7 of 165 CoNS isolates from mastitis milk samples carried the mecA gene (4.2\%) and $1.6 \%$ (3/192) of $S$. aureus isolates were classified as MRSA (de Jong et al., 2018). In Finland, two studies reported that $5.2 \%(17 / 324)$ and $1.8 \%(2 / 110)$ of the CoNS isolates were $m e c A$ positive and MRSA prevalence among $S$. aureus isolates was $1.5 \%$ (2/135) (Gindonis et al., 2013). A study from Portugal did not find MRSA but 9.3\% (19/204) of mastitis milk samples were positive for MR-CoNS (Seixas et al., 2014). In conclusion, MR-CoNS have been detected in MRSA affected dairy herds and the prevalence of methicillin resistance was generally higher than in $S$. aureus.

A study from Belgium reported that SCCmec types in bovine MR-CoNS $(n=101)$ differed from those mostly detected in LA-MRSA CC398 (Vanderhaeghen et al., 2013). The authors assumed that the SCCmec of MR-CoNS is probably not a reservoir of resistance determinants for LAMRSA CC398. However, it is well known that resistance genes can be transferred between staphylococcal species (Morikawa et al., 2012; Chlebowicz et al., 2014; Ray et al., 2016). The in vivo transfer of SCCmec was the most probable explanation for identical SCCmec in S. aureus and Staphylocccus epidermidis in an infected patient, although transmission could not be reproduced in vitro (Bloemendaal et al., 2010). In vitro, the transfer of SCCmec was achieved through transformation (incorporation of DNA from the environment) (Morikawa et al., 2012), through plasmids (Ray et al., 2016), conjugation (sexual transfer) (Tsubakishita et al., 2010), and transduction (bacteriophage transfer) (Chlebowicz et al., 2014). All these studies were performed under laboratory conditions. To the best of our knowledge, it remains unclear which mechanism(s) of SCCmec transfer occur in vivo. In conclusion, MR-CoNS could act as a reservoir of resistance genes that may be transferred to MSSA in dairy cows. The role of SCCmec transfer for the development of new MRSA strains needs to be further investigated.

\section{The Amount of Antibiotics Used on Dairy Farms}

The use of antibiotics is associated with the development of antibiotic resistance (Chantziaras et al., 2014). Every time bacteria are exposed to antimicrobial agents, selection pressure will cause antibiotic resistance to increase (Lam et al., 2014). A meta-analysis reported a significant association between antimicrobial exposure and the number of MRSA isolates in humans (Tacconelli et al., 2008).

For dairy cows, mastitis is the leading cause of antibiotic treatment. Blanket DCT with long-acting $\beta$-lactam antimicrobials, especially cloxacillin, is still commonly applied to prevent and cure intramammary $S$. aureus infections (Oliver et al., 2011; Saini et al., 2012a; Oliveira et al., 2016). Therefore, it is hypothesized that the large-scale use of $\beta$ lactams in dairy cows is a possible risk factor for the selection of new MRSA strains (Saini et al., 2012c).

A study from Germany found a lower MRSA prevalence in organic herds $(1.7 \%)$ than in conventional herds $(9.7 \%)$ (Tenhagen et al., 2018). Organic farmers are considered to use fewer antibiotics. In a study from the Netherlands, veal calves were more often MRSA carriers when treated with antibiotics (Graveland et al., 2010).
Unfortunately, most studies that included the amount of antibiotics used on dairy farms only performed phenotypic resistance testing and did not detect the mecA/mecC gene. This matters, since phenotypic testing was shown to lead to false-negative (Pu et al., 2014; Guimaraes et al., 2017) and false-positive results in previous studies (Cicconi-Hogan et al., 2014; da Costa Krewer et al., 2015; Li et al., 2015; de Jong et al., 2018; Wang et al., 2018). In Thailand, milk samples from 78 cows on 18 farms were tested for phenotypic oxacillin resistance (Suriyasathaporn et al., 2012). The authors reported higher numbers of methicillin resistant staphylococci on farms with high antibiotic use (21\%) than on farms with normal use of antibiotics $(5.9 \%)$. High antibiotic use was defined as more than two treatment periods per cow per year and normal use as no more than two treatment periods per cow per year. One study from Canada has found a positive correlation between intramammary and systematically administered penicillin treatments and phenotypic penicillin resistance in 89 dairy herds (Saini et al., 2012c).

A study from the United States included 2778 mastitis isolates for phenotypic antibiotic susceptibility testing over a 6-year period, from 1994 to 2000. The proportion of isolates, which were phenotypically susceptible to $\beta$-lactam antimicrobials, did not change during the period (Erskine et al., 2002). Another study from the United States has not reported a higher proportion of $S$. aureus isolates that were phenotypically resistant to any antimicrobial drug (Makovec and Ruegg, 2003a). In a literature review about the impact of antibiotic use in dairy cows on antimicrobial resistance, the authors concluded that there is no evidence for increasing resistance rates due to antibiotic treatment (Oliver et al., 2011).

In conclusion, there is an ongoing debate about the role of antimicrobial exposure as a risk factor for the occurrence of MRSA in dairy cows. It was suggested that antimicrobial resistance is low in milk because the total number of bacteria in the udder is low in comparison to the intestinal tract, skin, or mucous membranes. For this reason, resistance levels through intramammary treatment might be lower than in other parts of the body after oral or parenteral application of antibiotics (Lam et al., 2014).

\section{Association of MRSA with a High Somatic Cell Count in Milk}

The somatic cell count is the number of cells present in milk (cells $/ \mathrm{mL}$ ). Beside some epithelial cells, the majority of somatic cells are cells from the immune system (Harmon, 1994). Therefore, a higher somatic cell count is considered a reflection of an inflammatory response in the mammary gland. The most reliable somatic cell count cutoff value for mastitis detection is between 200,000 and 250,000 cells $/ \mathrm{mL}$ (Laevens et al., 1997; Schepers et al., 1997; Schukken, 2007).

A German study has reported that quarters harboring MRSA had a higher somatic cell count than other quarters (Spohr et al., 2011). In a case report about MRSA in a Brazilian dairy herd, the bulk milk somatic cell count was 628,000 cells/mL (Guimaraes et al., 2017). In Sicily, a negative correlation between somatic cell count and MRSA status in BTM from 45 dairy farms was reported (Antoci et al., 2013). A study from Italy detected higher somatic cell counts $(286,000 \pm 212,000$ cells/mL) in BTM from MRSAaffected farms in comparison to farms with negative test 
results $(236,000 \pm 231,000$ cells $/ \mathrm{mL})$ (Locatelli et al., 2016). However, this difference was not significant $(p=0.38)$. Two Italian studies sampled milk from MRSA-infected cow(s) continuously over the entire lactation. The somatic cell count in MRSA-infected quarters fluctuated between 300,000 and $6,000,000$ cells $/ \mathrm{mL}$ in one study and between 1000 and $1,800,000$ cells $/ \mathrm{mL}$ in the other study (Pilla et al., 2012; Magro et al., 2018). In one study, the authors reported that fluctuation was not related to the shedding of MRSA (Pilla et al., 2012). A Swedish case study reported somatic cell counts between 12,000 and 2,885,000 cells/mL in MRSApositive milk samples (Unnerstad et al., 2018). In China, 5 MRSA isolates have been reported among 121 quarter milk samples. All 5 MRSA were isolated from clinically healthy cows with a somatic cell count $<300,000$ cells/mL (Bao et al., 2016). In a case report from Japan, the authors have reported a low bulk tank somatic cell count of 114,000 cells/mL in a MRSA-affected herd (Hata, 2016). The somatic cell count in a German dairy herd with high MRSA prevalence was even lower with 51,600 cells/mL (Schlotter et al., 2014). Thus, a higher somatic cell count in milk is probably not a reliable indicator for the occurrence of MRSA in dairy herds.

\section{Additional Risk Factors for Udder Infections Caused by $S$. aureus in Dairy Cows That Have Not Been Addressed in Studies on MRSA}

Some studies have suggested that older cows are more likely to be S. aureus infected (Pyörälä and Pyörälä, 1998; Barkema et al., 2006). Moreover, a study found higher rates of phenotypic penicillin resistance in animals from the third and following lactations, than in animals from the first and second lactation (Sol et al., 2000). In addition, a larger mammary gland size was shown to be predisposing for $S$. aureus infections and hind quarters were more frequently affected (Deluyker et al., 2005). Furthermore, it has been known that purchasing infected replacement heifers and people that have visited many farms per day (e.g., veterinarians, artificial insemination technicians, and cattle traders) might introduce new $S$. aureus strains into dairy herds (Middleton et al., 2002). Moreover, some studies have found multiple different $S$. aureus strains within dairy herds, suggesting that in some cases $S$. aureus might be regarded as a sporadic environmental pathogen (Sommerhäuser et al., 2003; Zadoks et al., 2011). S. aureus has been detected in environmental samples, such as, flies, bedding materials, and feedstuff (Roberson et al., 1998; Capurro et al., 2010; Zadoks et al., 2011). Further studies are needed to confirm these findings for MRSA in dairy farms.

\section{Conclusion}

The risk factors for the transmission of MRSA into dairy herds are direct or indirect contact with pigs and humans carrying MRSA. Within dairy herds, MR-CoNS may transfer resistance genes to MSSA. Moreover, improper milking hygiene procedures enhance the spread of MRSA within herds as is well known for MSSA. There is some evidence that conventional dairy farms and farms with a larger herd size are more often affected by MRSA. The association of antimicrobial exposure and MRSA prevalence in dairy herds needs to be further investigated. High amounts of $\beta$-lactam antibiotics have been used for dry cow treatment and mastitis therapy on dairy farms. Nevertheless, MRSA prevalence is low in dairy cows. Furthermore, it is not known whether additional risk factors for $S$. aureus transmission in dairy herds differ from those of MRSA. According to our findings, a higher somatic cell count in milk is probably not a reliable indicator for the occurrence of MRSA in dairy herds.

The risk of foodborne zoonotic MRSA infections through consumption of milk seems to be low. Milk is usually heat treated before marketing and consumption and MRSA prevalence is low in milk from dairy cows. However, MRSA prevalence should be carefully monitored, since some studies suggest increasing levels of resistance.

In veterinary medicine, MRSA emerge as mastitis pathogens in dairy cows and spread within herds. Dry cow treatment with $\beta$-lactam antibiotics, as an important part of $S$. aureus control programs, is probably ineffective in curing MRSA infections. Therefore, segregation and culling of infected cows often remains the only option for removing MRSA from dairy herds. In conclusion, we stress the need for a continuous MRSA monitoring in dairy herds and the development of MRSA prevention strategies.

\section{Disclosure Statement}

No competing financial interests exist.

\section{Funding Information}

This study was carried out in the framework of the project \#1HealthPREVENT, funded by the German Federal Ministry of Education and Science, Grant No. 01KI1727C.

\section{References}

Abraham S, Jagoe S, Pang S, Coombs GW, O’Dea M, Kelly J, Khazandi M, Petrovski KR, Trott DJ. Reverse zoonotic transmission of community-associated MRSA ST1-IV to a dairy cow. Int J Antimicrob Agents 2017;50:125-126.

Abreu R, Rodriguez-Alvarez C, Lecuona M, Castro B, Gonzalez JC, Aguirre-Jaime A, Arias A. Increased antimicrobial resistance of MRSA strains isolated from pigs in Spain between 2009 and 2018. Vet Sci 2019;6(38):1-7.

Ahangari Z, Ghorbanpoor M, Shapouri MRS, Gharibi D, Ghazvini K. Methicillin resistance and selective genetic determinants of Staphylococcus aureus isolates with bovine mastitis milk origin. Iran J Microbiol 2017;9:152-159.

Al-Ashmawy MA, Sallam KI, Abd-Elghany SM, Elhadidy M, Tamura T. Prevalence, molecular characterization, and antimicrobial susceptibility of methicillin-resistant Staphylococcus aureus isolated from milk and dairy products. Foodborne Pathog Dis 2016;13:156-162.

Alba P, Feltrin F, Cordaro G, Porrero MC, Kraushaar B, Argudin MA, Nykasenoja S, Monaco M, Stegger M, Aarestrup FM, Butaye P, Franco A, Battisti A. Livestock-associated methicillin resistant and methicillin susceptible Staphylococcus aureus sequence type (CC)1 in European farmed animals: High genetic relatedness of isolates from italian cattle herds and humans. PLoS One 2015;10:e0137143.

Antoci E, Pinzone MR, Nunnari G, Stefani S, Cacopardo B. Prevalence and molecular characteristics of methicillin- 
resistant Staphylococcus aureus (MRSA) among subjects working on bovine dairy farms. Infez Med 2013;21:125-129.

Armand-Lefevre L, Ruimy R, Andremont A. Clonal comparison of Staphylococcus aureus isolates from healthy pig farmers, human controls, and pigs. Emerg Infect Dis 2005;11:711-714.

Aslantas O, Demir C. Investigation of the antibiotic resistance and biofilm-forming ability of Staphylococcus aureus from subclinical bovine mastitis cases. J Dairy Sci 2016;99:86078613.

Åvall-Jääskeläinen S, Taponen S, Kant R, Paulin L, Blom J, Palva A, Koort J. Comparative genome analysis of 24 bovineassociated Staphylococcus isolates with special focus on the putative virulence genes. PeerJ 2018;6:e4560.

Bao H, Hui Z, Yan Z, Lili Z, Ran W. Prevalence, enterotoxin gene and antimicrobial resistance of Staphylococcus aureus and methicillin-resistant Staphylococcus aureus from clinical healthy dairy cows. Pak Vet J 2016;36:270-274.

Bardiau M, Yamazaki K, Duprez JN, Taminiau B, Mainil JG, Ote I. Genotypic and phenotypic characterization of methicillinresistant Staphylococcus aureus (MRSA) isolated from milk of bovine mastitis. Lett Appl Microbiol 2013;57:181-186.

Barkema HW, Schukken YH, Zadoks RN. Invited review: The role of cow, pathogen, and treatment regimen in the therapeutic success of bovine Staphylococcus aureus mastitis. J Dairy Sci 2006;89:1877-1895.

Bengtsson B, Unnerstad HE, Ekman T, Artursson K, NilssonOst M, Waller KP. Antimicrobial susceptibility of udder pathogens from cases of acute clinical mastitis in dairy cows. Vet Microbiol 2009;136:142-149.

Bennedsgaard TW, Thamsborg SM, Aarestrup FM, Enevoldsen C, Vaarst M, Christoffersen AB. Resistance to penicillin of Staphylococcus aureus isolates from cows with high somatic cell counts in organic and conventional dairy herds in Denmark. Acta Vet Scand 2006;48:24.

Bervoets E. The incidence of methicillin-resistant Staphylococcus aureus in milk samples of Canadian dairy cows. Doctoral thesis, Faculty of Veterinary Medicine, University of Calgary, Calgary, 2009.

Bloemendaal AL, Brouwer EC, Fluit AC. Methicillin resistance transfer from Staphylocccus epidermidis to methicillinsusceptible Staphylococcus aureus in a patient during antibiotic therapy. PLoS One 2010;5:e11841.

Capurro A, Aspan A, Ericsson Unnerstad H, Persson Waller K, Artursson K. Identification of potential sources of Staphylococcus aureus in herds with mastitis problems. J Dairy Sci 2010;93:180-191.

Chantziaras I, Boyen F, Callens B, Dewulf J. Correlation between veterinary antimicrobial use and antimicrobial resistance in food-producing animals: A report on seven countries. J Antimicrob Chemother 2014;69:827-834.

Chlebowicz MA, Maslanova I, Kuntova L, Grundmann H, Pantucek R, Doskar J, van Dijl JM, Buist G. The staphylococcal cassette chromosome mec type V from Staphylococcus aureus ST398 is packaged into bacteriophage capsids. Int J Med Microbiol 2014;304:764-774.

Cicconi-Hogan KM, Belomestnykh N, Gamroth M, Ruegg PL, Tikofsky L, Schukken YH. Short communication: Prevalence of methicillin resistance in coagulase-negative staphylococci and Staphylococcus aureus isolated from bulk milk on organic and conventional dairy farms in the United States. J Dairy Sci 2014;97:2959-2964.

Cortimiglia C, Luini M, Bianchini V, Marzagalli L, Vezzoli F, Avisani D, Bertoletti M, Ianzano A, Franco A, Battisti A. Prevalence of Staphylococcus aureus and of methicillin- resistant $S$. aureus clonal complexes in bulk tank milk from dairy cattle herds in Lombardy Region (Northern Italy). Epidemiol Infect 2016;144:3046-3051.

da Costa Krewer C, Santos Amanso E, Veneroni Gouveia G, de Lima Souza R, da Costa MM, Aparecido Mota R. Resistance to antimicrobials and biofilm formation in Staphylococcus spp. isolated from bovine mastitis in the Northeast of Brazil. Trop Anim Health Prod 2015;47:511-518.

Dan M, Yehui W, Qingling M, Jun Q, Xingxing Z, Shuai M, Kuojun C, Jinsheng Z, Zibing C, Zaichao Z, Xuepeng C. Antimicrobial resistance, virulence gene profiles and molecular typing of Staphylococcus aureus isolates from dairy cows in Xinjiang, Northwest of China. J Glob Antimicrob Resist 2018;16:98-104.

de Jong A, Garch FE, Simjee S, Moyaert H, Rose M, Youala M, Siegwart E; VetPath Study Group. Monitoring of antimicrobial susceptibility of udder pathogens recovered from cases of clinical mastitis in dairy cows across Europe: VetPath results. Vet Microbiol 2018;213:73-81.

Deluyker HA, Van Oye SN, Boucher JF. Factors affecting cure and somatic cell count after pirlimycin treatment of subclinical mastitis in lactating cows. J Dairy Sci 2005;88:604-614.

Erskine RJ, Walker RD, Bolin CA, Bartlett PC, White DG. Trends in antibacterial susceptibility of mastitis pathogens during a seven-year period. J Dairy Sci 2002;85:1111-1118.

Falk R. Unusual outbreak of mastitis caused by methicillinresistant Staphylococcus aureus (MRSA) in a dairy herd in winter 2018. Animal Health Report-International Dairy Federation 2018:9-10. https://www.fil-idf.org/wp-content/uploads/ 2018/09/IDF-Animal-Health-Report-Web.pdf accessed August 14, 2019.

Feltrin F, Alba P, Kraushaar B, Ianzano A, Argudin MA, Di Matteo P, Porrero MC, Aarestrup FM, Butaye P, Franco A, Battisti A. A Livestock-associated, multidrug-resistant, methicillin-resistant Staphylococcus aureus clonal complex 97 lineage spreading in dairy cattle and pigs in Italy. Appl Environ Microbiol 2016;82:816-821.

Fessler A, Scott C, Kadlec K, Ehricht R, Monecke S, Schwarz S. Characterization of methicillin-resistant Staphylococcus aureus ST398 from cases of bovine mastitis. J Antimicrob Chemother 2010;65:619-625.

Fitzgerald JR. Livestock-associated Staphylococcus aureus: Origin, evolution and public health threat. Trends Microbiol 2012;20:192-198.

Fluit AC. Livestock-associated Staphylococcus aureus. Clin Microbiol Infect 2012;18:735-744.

Garcia-Alvarez L, Holden MT, Lindsay H, Webb CR, Brown DF, Curran MD, Walpole E, Brooks K, Pickard DJ, Teale C, Parkhill J, Bentley SD, Edwards GF, Girvan EK, Kearns AM, Pichon B, Hill RL, Larsen AR, Skov RL, Peacock SJ, Maskell DJ, Holmes MA. Meticillin-resistant Staphylococcus aureus with a novel mecA homologue in human and bovine populations in the UK and Denmark: A descriptive study. Lancet Infect Dis 2011;11:595-603.

Gindonis V, Taponen S, Myllyniemi AL, Pyorala S, Nykasenoja S, Salmenlinna S, Lindholm L, Rantala M. Occurrence and characterization of methicillin-resistant staphylococci from bovine mastitis milk samples in Finland. Acta Vet Scand 2013;55:61.

Graveland H, Wagenaar JA, Heesterbeek H, Mevius D, van Duijkeren E, Heederik D. Methicillin resistant Staphylococcus aureus ST398 in veal calf farming: Human MRSA carriage related with animal antimicrobial usage and farm hygiene. PLoS One 2010;5:e10990. 
Guimaraes FF, Manzi MP, Joaquim SF, Richini-Pereira VB, Langoni H. Short communication: Outbreak of methicillinresistant Staphylococcus aureus (MRSA)-associated mastitis in a closed dairy herd. J Dairy Sci 2017;100:726-730.

Haenni M, Galofaro L, Ponsin C, Bes M, Laurent F, Madec JY. Staphylococcal bovine mastitis in France: Enterotoxins, resistance and the human Geraldine methicillin-resistant Staphylococcus aureus clone. J Antimicrob Chemother 2011;66: 216-218.

Haran KP, Godden SM, Boxrud D, Jawahir S, Bender JB, Sreevatsan S. Prevalence and characterization of Staphylococcus aureus, including methicillin-resistant Staphylococcus aureus, isolated from bulk tank milk from Minnesota dairy farms. J Clin Microbiol 2012;50:688-695.

Harmon RJ. Physiology of mastitis and factors affecting somatic cell counts. J Dairy Sci 1994;77:2103-2112.

Harrison EM, Paterson GK, Holden MT, Larsen J, Stegger M, Larsen AR, Petersen A, Skov RL, Christensen JM, Bak Zeuthen A, Heltberg O, Harris SR, Zadoks RN, Parkhill J, Peacock SJ, Holmes MA. Whole genome sequencing identifies zoonotic transmission of MRSA isolates with the novel mecA homologue mecC. EMBO Mol Med 2013;5: 509-515.

Hata E. Bovine mastitis outbreak in Japan caused by methicillinresistant Staphylococcus aureus New York/Japan clone. J Vet Diagn Invest 2016;28:291-298.

Hata E, Katsuda K, Kobayashi H, Uchida I, Tanaka K, Eguchi M. Genetic variation among Staphylococcus aureus strains from bovine milk and their relevance to methicillin-resistant isolates from humans. J Clin Microbiol 2010;48:2130-2139.

Holmes MA, Zadoks RN. Methicillin resistant S. aureus in human and bovine mastitis. J Mammary Gland Biol Neoplasia 2011;16:373-382.

Huber H, Koller S, Giezendanner N, Stephan R, Zweifel C. Prevalence and characteristics of meticillin-resistant Staphylococcus aureus in humans in contact with farm animals, in livestock, and in food of animal origin, Switzerland, 2009. Euro Surveill 2010;15(16):1-4.

Huijsdens XW, van Dijke BJ, Spalburg E, Santen-Verheuvel MG, Heck ME, Pluister GN, Voss A, Wannet WJ, de Neeling AJ. Community-acquired MRSA and pig-farming. Ann Clin Microbiol Antimicrob 2006;5:26.

Jamali H, Paydar M, Radmehr B, Ismail S, Dadrasnia A. Prevalence and antimicrobial resistance of Staphylococcus aureus isolated from raw milk and dairy products. Food Control 2015;54:383-388.

Jamali H, Radmehr B, Ismail S. Short communication: Prevalence and antibiotic resistance of Staphylococcus aureus isolated from bovine clinical mastitis. J Dairy Sci 2014;97: 2226-2230.

Juhasz-Kaszanyitzky E, Janosi S, Somogyi P, Dan A, van der Graaf-van Bloois L, van Duijkeren E, Wagenaar JA. MRSA transmission between cows and humans. Emerg Infect Dis 2007;13:630-632.

Kamal RM, Bayoumi MA, Abd El Aal SFA. MRSA detection in raw milk, some dairy products and hands of dairy workers in Egypt, a mini-survey. Food Control 2013;33:49-53.

Keefe G. Update on control of Staphylococcus aureus and Streptococcus agalactiae for management of mastitis. Vet Clin North Am Food Anim Pract 2012;28:203-216.

Kreausukon K, Fetsch A, Kraushaar B, Alt K, Muller K, Kromker V, Zessin KH, Kasbohrer A, Tenhagen BA. Prevalence, antimicrobial resistance, and molecular characterization of methicillin-resistant Staphylococcus aureus from bulk tank milk of dairy herds. J Dairy Sci 2012;95:4382_ 4388.

Kumar R, Yadav BR, Singh RS. Genetic determinants of antibiotic resistance in Staphylococcus aureus isolates from milk of mastitic crossbred cattle. Curr Microbiol 2010;60:379386.

Kwon NH, Park KT, Moon JS, Jung WK, Kim SH, Kim JM, Hong SK, Koo HC, Joo YS, Park YH. Staphylococcal cassette chromosome mec (SCCmec) characterization and molecular analysis for methicillin-resistant Staphylococcus aureus and novel SCCmec subtype IVg isolated from bovine milk in Korea. J Antimicrob Chemother 2005;56:624-632.

Laevens H, Deluyker H, Schukken YH, De Meulemeester L, Vandermeersch R, De Muelenaere E, De Kruif A. Influence of parity and stage of lactation on the somatic cell count in bacteriologically negative dairy cows. J Dairy Sci 1997;80: 3219-3226.

Lam T, Scherpenzeel CGM, den Uijl IE, van Schaik G. Dry cow therapy: Does it still deserve a blanked recommendation? Fort Worth, TX: National Mastitis Council, 53rd Annual Meeting Proceedings. 2014:64-72.

Lee JH. Methicillin (oxacillin)-resistant Staphylococcus aureus strains isolated from major food animals and their potential transmission to humans. Appl Environ Microbiol 2003;69: 6489-6494.

Li L, Zhou L, Wang L, Xue H, Zhao X. Characterization of methicillin-resistant and -susceptible staphylococcal isolates from bovine milk in northwestern China. PLoS One 2015;10: e0116699.

Lim SK, Nam HM, Jang GC, Lee HS, Jung SC, Kim TS. Transmission and persistence of methicillin-resistant Staphylococcus aureus in milk, environment, and workers in dairy cattle farms. Foodborne Pathog Dis 2013;10:731736.

Locatelli C, Cremonesi P, Bertocchi L, Zanoni MG, Barberio A, Drigo I, Varisco G, Castiglioni B, Bronzo V, Moroni P. Short communication: Methicillin-resistant Staphylococcus aureus in bulk tank milk of dairy cows and effect of swine population density. J Dairy Sci 2016;99:2151-2156.

Locatelli C, Cremonesi P, Caprioli A, Carfora V, Ianzano A, Barberio A, Morandi S, Casula A, Castiglioni B, Bronzo V, Moroni P. Occurrence of methicillin-resistant Staphylococcus aureus in dairy cattle herds, related swine farms, and humans in contact with herds. J Dairy Sci 2017;100:608-619.

Luini M, Cremonesi P, Magro G, Bianchini V, Minozzi G, Castiglioni B, Piccinini R. Methicillin-resistant Staphylococcus aureus (MRSA) is associated with low within-herd prevalence of intra-mammary infections in dairy cows: Genotyping of isolates. Vet Microbiol 2015;178:270-274.

Magro G, Rebolini M, Beretta D, Piccinini R. Methicillinresistant Staphylococcus aureus CC22-MRSA-IV as an agent of dairy cow intramammary infections. Vet Microbiol 2018; 227:29-33.

Makovec JA, Ruegg DPL. Antimicrobial resistance of bacteria isolated from dairy cow milk samples submitted for bacterial culture: 8,905 samples (1994-2001). J Am Vet Med Assoc 2003a;222:1582-1589.

Makovec JA, Ruegg PL. Results of milk samples submitted for microbiological examination in Wisconsin from 1994 to 2001. J Dairy Sci 2003b;86:3466-3472.

Matyi SA, Dupre JM, Johnson WL, Hoyt, PR, White DG, Brody $\mathrm{T}$, Odenwald WF, Gustafson JE. Isolation and characterization of Staphylococcus aureus strains from a Paso del Norte dairy. J Dairy Sci 2013;96;3535-3542. 
Mekonnen SA, Lam T, Hoekstra J, Rutten V, Tessema TS, Broens EM, Riesebos AE, Spaninks MP, Koop G. Characterization of Staphylococcus aureus isolated from milk samples of dairy cows in small holder farms of NorthWestern Ethiopia. BMC Vet Res 2018;14:246.

Middleton JR, Fox LK, Gay JM, Tyler JW, Besser TE. Use of pulsed-field gel electrophoresis for detecting differences in Staphylococcus aureus strain populations between dairy herds with different cattle importation practices. Epidemiol Infect 2002;129:387-395.

Miragaia M. Factors contributing to the evolution of mecAmediated beta-lactam resistance in staphylococci: Update and new insights from whole genome sequencing (WGS). Front Microbiol 2018;9:2723.

Monecke S, Kuhnert P, Hotzel H, Slickers P, Ehricht R. Microarray based study on virulence-associated genes and resistance determinants of Staphylococcus aureus isolates from cattle. Vet Microbiol 2007;125:128-140.

Moon JS, Lee AR, Kang HM, Lee ES, Kim MN, Paik YH, Park YH, Joo YS, Koo HC. Phenotypic and genetic antibiogram of methicillin-resistant staphylococci isolated from bovine mastitis in Korea. J Dairy Sci 2007;90:1176-1185.

Morikawa K, Takemura AJ, Inose Y, Tsai M, Nguyen Thi le T, Ohta T, Msadek T. Expression of a cryptic secondary sigma factor gene unveils natural competence for DNA transformation in Staphylococcus aureus. PLoS Pathog 2012;8: e1003003.

Nam HM, Lee AL, Jung SC, Kim MN, Jang GC, Wee SH, Lim SK. Antimicrobial susceptibility of Staphylococcus aureus and characterization of methicillin-resistant Staphylococcus aureus isolated from bovine mastitis in Korea. Foodborne Pathog Dis 2011;8:231-238.

Nemeghaire S, Argudin MA, Haesebrouck F, Butaye P. Epidemiology and molecular characterization of methicillin-resistant Staphylococcus aureus nasal carriage isolates from bovines. BMC Vet Res 2014;10:153.

Obaidat MM, Salman AEB, Roess AA. High prevalence and antimicrobial resistance of mecA Staphylococcus aureus in dairy cattle, sheep, and goat bulk tank milk in Jordan. Trop Anim Health Prod 2018;50:405-412.

Olde Riekerink RGM, Sampimon OC, Rothkamp A, Lam TJGM. Prevalence of MRSA intramammary infections and risk factors in Dutch dairy herds. Proceedings ISVEE XII, Durban, South Africa. 2009:1-3.

Oliveira CJ, Tiao N, de Sousa FG, de Moura JF, Santos Filho L, Gebreyes WA. Methicillin-resistant Staphylococcus aureus from Brazilian dairy farms and identification of novel sequence types. Zoonoses Public Health 2016;63:97105.

Oliver SP, Murinda SE, Jayarao BM. Impact of antibiotic use in adult dairy cows on antimicrobial resistance of veterinary and human pathogens: A comprehensive review. Foodborne $\mathrm{Pa}-$ thog Dis 2011;8:337-355.

Østerås $\mathrm{O}$. Animal health and welfare: Results of the IDF questionnaire. Animal Health Report-International Dairy Federation. 2018:18-23. https://www.fil-idf.org/wp-content/uploads/ 2018/09/IDF-Animal-Health-Report-Web.pdf accessed August 14, 2019.

Papadopoulos P, Papadopoulos T, Angelidis AS, Boukouvala E, Zdragas A, Papa A, Hadjichristodoulou C, Sergelidis D. Prevalence of Staphylococcus aureus and of methicillinresistant $S$. aureus (MRSA) along the production chain of dairy products in north-western Greece. Food Microbiol 2018; 69:43-50.
Parisi A, Caruso M, Normanno G, Latorre L, Sottili R, Miccolupo A, Fraccalvieri R, Santagada G. Prevalence, antimicrobial susceptibility and molecular typing of methicillin-resistant Staphylococcus aureus (MRSA) in bulk tank milk from southern Italy. Food Microbiol 2016;58:36-42.

Paterson GK, Larsen J, Harrison EM, Larsen AR, Morgan FJ, Peacock SJ, Parkhill J, Zadoks RN, Holmes MA. First detection of livestock-associated meticillin-resistant Staphylococcus aureus CC398 in bulk tank milk in the United Kingdom, January to July 2012. Euro Surveill 2012;17(50): $1-7$.

Paterson GK, Morgan FJ, Harrison EM, Peacock SJ, Parkhill J, Zadoks RN, Holmes MA. Prevalence and properties of mecC methicillin-resistant Staphylococcus aureus (MRSA) in bovine bulk tank milk in Great Britain. J Antimicrob Chemother 2014;69:598-602.

Pilla R, Castiglioni V, Gelain ME, Scanziani E, Lorenzi V, Anjum M, Piccinini R. Short communications: Long-term study of MRSA ST1, t127 mastitis in a dairy cow. Vet Rec 2012;170.

Pitkälä A, Haveri M, Pyörälä S, Myllys V, Honkanen-Buzalski T. Bovine mastitis in Finland 2001-Prevalence, distribution of bacteria, and antimicrobial resistance. J Dairy Sci 2004;87: 2433-2441.

Porrero MC, Wassenaar TM, Gomez-Barrero S, Garcia M, Barcena C, Alvarez J, Saez-Llorente JL, FernandezGarayzabal JF, Moreno MA, Dominguez L. Detection of methicillin resistant Staphylococcus aureus in Iberian pigs. Lett Appl Microbiol 2012;54:280-285.

Pu W, Su Y, Li J, Li C, Yang Z, Deng H, Ni C. High incidence of oxacillin-susceptible mecA-positive Staphylococcus aureus (OS-MRSA) associated with bovine mastitis in China. PLoS One 2014;9:e88134.

Pyörälä SH, Pyörälä EO. Efficacy of parenteral administration of three antimicrobial agents in treatment of clinical mastitis in lactating cows: 487 cases (1989-1995). J Am Vet Med Assoc 1998;212:407-412.

Qu Y, Zhao H, Nobrega DB, Cobo ER, Han B, Zhao Z, Li S, Li M, Barkema HW, Gao J. Molecular epidemiology and distribution of antimicrobial resistance genes of Staphylococcus species isolated from Chinese dairy cows with clinical mastitis. J Dairy Sci 2018;102(2):1571-1583.

Ray MD, Boundy S, Archer GL. Transfer of the methicillin resistance genomic island among staphylococci by conjugation. Mol Microbiology 2016;100:675-685.

Riva A, Borghi E, Cirasola D, Colmegna S, Borgo F, Amato E, Pontello MM, Morace G. Methicillin-resistant Staphylococcus aureus in raw milk: Prevalence, SCCmec typing, enterotoxin characterization, and antimicrobial resistance patterns. J Food Prot 2015;78:1142-1146.

Roberson JR, Fox LK, Hancock DD, Gay JM, Besser TE. Sources of intramammary infections from Staphylococcus aureus in dairy heifers at first parturition. J Dairy Sci 1998; 81:687-693.

Rola JG, Korpysa-Dzirba W, Czubkowska A, Osek J. Prevalence of enterotoxin genes and antimicrobial resistance of coagulase-positive staphylococci recovered from raw cow milk. J Dairy Sci 2015;98:4273-4278.

Ronco T, Klaas IC, Stegger M, Svennesen L, Astrup LB, Farre M, Pedersen K. Genomic investigation of Staphylococcus aureus isolates from bulk tank milk and dairy cows with clinical mastitis. Vet Microbiol 2018;215:35-42.

Ruegg PL, Oliveira L, Jin W, Okwumabua O. Phenotypic antimicrobial susceptibility and occurrence of selected re- 
sistance genes in gram-positive mastitis pathogens isolated from Wisconsin dairy cows. J Dairy Sci 2015;98;4521-4534.

Ruegg PL. Making antibiotic treatment decisions for clinical mastitis. Vet Clin North Am Food Anim Pract 2018;34:413425.

Saini V, McClure JT, Leger D, Dufour S, Sheldon AG, Scholl DT, Barkema HW. Antimicrobial use on Canadian dairy farms. J Dairy Sci 2012a;95:1209-1221.

Saini V, McClure JT, Leger D, Keefe GP, Scholl DT, Morck DW, Barkema HW. Antimicrobial resistance profiles of common mastitis pathogens on Canadian dairy farms. J Dairy Sci 2012b;95:4319-4332.

Saini V, McClure JT, Scholl DT, DeVries TJ, Barkema HW. Herd-level association between antimicrobial use and antimicrobial resistance in bovine mastitis Staphylococcus aureus isolates on Canadian dairy farms. J Dairy Sci 2012c;95:19211929.

Sampimon O, Barkema HW, Berends I, Sol J, Lam T. Prevalence of intramammary infection in Dutch dairy herds. J Dairy Res 2009;76:129-136.

Schepers AJ, Lam TJ, Schukken YH, Wilmink JB, Hanekamp WJ. Estimation of variance components for somatic cell counts to determine thresholds for uninfected quarters. J Dairy Sci 1997;80:1833-1840.

Schlotter K, Huber-Schlenstedt R, Gangl A, Hotzel H, Monecke S, Muller E, Reissig A, Proft S, Ehricht R. Multiple cases of methicillin-resistant CC130 Staphylococcus aureus harboring mecC in milk and swab samples from a Bavarian dairy herd. J Dairy Sci 2014;97:2782-2788.

Schukken YH. Using SCC data to your best advantage. NMC Regional Meeting Proceedings 2007, Visalia, CA, 2007: 29-35.

Seixas R, Santos JP, Bexiga R, Vilela CL, Oliveira M. Short communication: Antimicrobial resistance and virulence characterization of methicillin-resistant staphylococci isolates from bovine mastitis cases in Portugal. J Dairy Sci 2014;97: 340-344.

Shrivastava N, Sharma V, Shrivastav A, Nayak A, Rai AK. Prevalence and characterization of Panton-Valentine leukocidin-positive Staphylococcus aureus in bovine milk in Jabalpur district of Madhya Pradesh, India. Vet World 2018; 11:316-320.

Silva NC, Guimaraes FF, Manzi MP, Junior AF, Gomez-Sanz E, Gomez P, Langoni H, Rall VL, Torres C. Methicillinresistant Staphylococcus aureus of lineage ST398 as cause of mastitis in cows. Lett Appl Microbiol 2014;59:665-669.

Sol J, Sampimon OC, Barkema HW, Schukken YH. Factors associated with cure after therapy of clinical mastitis caused by Staphylococcus aureus. J Dairy Sci 2000;83:278-284.

Sommerhäuser J, Kloppert B, Wolter W, Zschock M, Sobiraj A, Failing K. The epidemiology of Staphylococcus aureus infections from subclinical mastitis in dairy cows during a control programme. Vet Microbiol 2003;96:91-102.

Song JW, Yang SJ, Shin S, Seo KS, Park YH, Park KT. Genotypic and phenotypic characterization of methicillinresistant Staphylococcus aureus isolated from bovine mastitic milk in Korea. J Food Prot 2016;79:1725-1732.

Spohr M, Rau J, Friedrich A, Klittich G, Fetsch A, Guerra B, Hammerl JA, Tenhagen BA. Methicillin-resistant Staphylococcus aureus (MRSA) in three dairy herds in southwest Germany. Zoonoses Public Health 2011;58:252-261.

Sun J, Yang M, Sreevatsan S, Davies PR. Prevalence and characterization of Staphylococcus aureus in growing pigs in the USA. PLoS One 2015;10:e0143670.
Suriyasathaporn W, Chupia V, Sing-Lah T, Wongsawan K, Mektrirat R, Chaisri W. Increases of antibiotic resistance in excessive use of antibiotics in smallholder dairy farms in northern Thailand. Asian-Australas J Anim Sci 2012;25: 1322-1328.

Tacconelli E, De Angelis G, Cataldo MA, Pozzi E, Cauda R. Does antibiotic exposure increase the risk of methicillinresistant Staphylococcus aureus (MRSA) isolation? A systematic review and meta-analysis. J Antimicrob Chemother 2008;61:26-38.

Tavakol M, Riekerink RG, Sampimon OC, van Wamel WJ, van Belkum A, Lam TJ. Bovine-associated MRSA ST398 in the Netherlands. Acta Vet Scand 2012;54:28.

Tenhagen BA, Alt K, Pfefferkorn B, Wiehle L, Kasbohrer A, Fetsch A. Short communication: Methicillin-resistant Staphylococcus aureus in conventional and organic dairy herds in Germany. J Dairy Sci 2018;101:3380-3386.

Tenhagen BA, Hansen I, Reinecke A, Heuwieser W. Prevalence of pathogens in milk samples of dairy cows with clinical mastitis and in heifers at first parturition. J Dairy Res 2009; 76:179-187.

Tenhagen BA, Koster G, Wallmann J, Heuwieser W. Prevalence of mastitis pathogens and their resistance against antimicrobial agents in dairy cows in Brandenburg, Germany. J Dairy Sci 2006;89:2542-2551.

Tenhagen BA, Vossenkuhl B, Kasbohrer A, Alt K, Kraushaar B, Guerra B, Schroeter A, Fetsch A. Methicillin-resistant Staphylococcus aureus in cattle food chains-Prevalence, diversity, and antimicrobial resistance in Germany. J Anim Sci 2014;92:2741-2751.

Tikofsky LL, Barlow JW, Santisteban C, Schukken YH. A comparison of antimicrobial susceptibility patterns for Staphylococcus aureus in organic and conventional dairy herds. Microb Drug Resist 2003;9(Suppl 1):S39-S45.

Tsubakishita S, Kuwahara-Arai K, Baba T, Hiramatsu K. Staphylococcal cassette chromosome mec-like element in Macrococcus caseolyticus. Antimicrob Agents Chemother 2010; 54:1469-1475.

Turkyilmaz S, Tekbiyik S, Oryasin E, Bozdogan B. Molecular epidemiology and antimicrobial resistance mechanisms of methicillin-resistant Staphylococcus aureus isolated from bovine milk. Zoonoses Public Health 2010;57:197-203.

Unnerstad HE, Bengtsson B, Horn af Rantzien M, Borjesson S. Methicillin-resistant Staphylococcus aureus containing mecC in Swedish dairy cows. Acta Vet Scand 2013;55:6.

Unnerstad HE, Mieziewska K, Borjesson S, Hedback H, Strand K, Hallgren T, Landin H, Skarin J, Bengtsson B. Suspected transmission and subsequent spread of MRSA from farmer to dairy cows. Vet Microbiol 2018;225:114-119.

van de Giessen AW, van Santen-Verheuvel MG, Hengeveld PD, Bosch T, Broens EM, Reusken CB. Occurrence of methicillin-resistant Staphylococcus aureus in rats living on pig farms. Prev Vet Med 2009;91:270-273.

van Duijkeren E, Hengeveld PD, Albers M, Pluister G, Jacobs P, Heres L, van de Giessen AW. Prevalence of methicillinresistant Staphylococcus aureus carrying mecA or mecC in dairy cattle. Vet Microbiol 2014;171:364-367.

Vanderhaeghen W, Cerpentier T, Adriaensen C, Vicca J, Hermans K, Butaye P. Methicillin-resistant Staphylococcus aureus (MRSA) ST398 associated with clinical and subclinical mastitis in Belgian cows. Vet Microbiol 2010;144:166-171.

Vanderhaeghen W, Vandendriessche S, Crombe F, Nemeghaire S, Dispas M, Denis O, Hermans K, Haesebrouck F, Butaye P. Characterization of methicillin-resistant non-Staphylococcus 
aureus staphylococci carriage isolates from different bovine populations. J Antimicrob Chemother 2013;68:300-307.

Virgin JE, Van Slyke TM, Lombard JE, Zadoks RN. Short communication: Methicillin-resistant Staphylococcus aureus detection in US bulk tank milk. J Dairy Sci 2009;92:49884991.

Visciano P, Pomilio F, Tofalo R, Sacchini L, Saletti MA, Tieri E, Schirone M, Suzzi G. Detection of methicillin-resistant Staphylococcus aureus in dairy cow farms. Food Control 2014;46:532-538.

Voss A, Loeffen F, Bakker J, Klaassen C, Wulf M. Methicillinresistant Staphylococcus aureus in pig farming. Emerg Infect Dis 2005;11:1965-1966.

Vyletělova M, Vlkova H, Manga I. Occurrence and characteristics of methicillin resistant Staphylococcus aureus and methicillin resistant coagulase-negative staphylococci in raw milk manufacturing. Czech J Food Sci 2011;29:S11-S16.

Wang W, Lin X, Jiang T, Peng Z, Xu J, Yi L, Li F, Fanning S, Baloch Z. Prevalence and characterization of Staphylococcus aureus cultured from raw milk taken from dairy cows with mastitis in Beijing, China. Front Microbiol 2018;9:1123.

Wang XM, Zhang WJ, Schwarz S, Yu SY, Liu H, Si W, Zhang RM, Liu S. Methicillin-resistant Staphylococcus aureus ST9 from a case of bovine mastitis carries the genes cfr and erm(A) on a small plasmid. J Antimicrob Chemother 2012; 67:1287-1289.
Yi Y, Su L, Li B, Li S, Zhang B, Su Y. Analysis of the genetic diversity in methicillin-resistant Staphylococcus aureus isolates from bovine subclinical mastitis case in Xinjiang, China. Foodborne Pathog Dis 2018;15:568-575.

Zadoks R, van Leeuwen W, Barkema H, Sampimon O, Verbrugh $\mathrm{H}$, Schukken $\mathrm{YH}$, van Belkum A. Application of pulsed-field gel electrophoresis and binary typing as tools in veterinary clinical microbiology and molecular epidemiologic analysis of bovine and human Staphylococcus aureus isolates. J Clin Microbiol 2000;38:1931-1939.

Zadoks RN, Middleton JR, McDougall S, Katholm J, Schukken $\mathrm{YH}$. Molecular epidemiology of mastitis pathogens of dairy cattle and comparative relevance to humans. J Mammary Gland Biol Neoplasia 2011;16:357-372.

Address correspondence to: Bernd-Alois Tenhagen, PhD Department Biological Safety German Federal Institute for Risk Assessment Max-Dohrn-Straße 8-10 10589 Berlin Germany

E-mail: bernd-alois.tenhagen@bfr.bund.de 